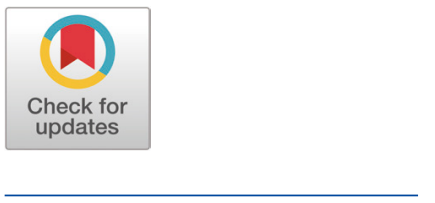

Received: Nov 22, 2019

Revised: Dec 5, 2019

Accepted: Dec 11, 2019

${ }^{*}$ Corresponding author Jin Ho Cho

Division of Food and Animal Science, Chungbuk National University,

Cheongju 28644, Korea.

Tel: +82-43-261-2544

E-mail: jinhcho@chungbuk.ac.kr

Copyright $\odot 2020$ Korean Society of Animal Sciences and Technology.

This is an Open Access article distributed under the terms of the Creative Commons Attribution Non-Commercial License (http:// creativecommons.org/licenses/bync/4.0/) which permits unrestricted non-commercial use, distribution, and reproduction in any medium, provided the original work is properly cited.

ORCID

Han Jin Oh

https://orcid.org/0000-0002-3396-483X Won Yun

https://orcid.org/0000-0002-1835-2640 Ji Hwan Lee

https://orcid.org/0000-0001-8161-4853 Ji Seon An

https://orcid.org/0000-0002-9205-8095

Tae Heon Kim

https://orcid.org/0000-0001-9054-5781

Eun Ah Cho

https://orcid.org/0000-0002-3445-1905

Beom Jun Park

https://orcid.org/0000-0001-6741-4716

Ki Hyun Kim

https://orcid.org/0000-0002-9834-2126

\section{Effect of replacing corn with soy hulls on nutrient digestibility of growing pigs}

\author{
Han Jin Oh ${ }^{1}$, Won Yun ${ }^{1}$, Ji Hwan Lee ${ }^{1}$, Ji Seon An¹, Tae Heon Kim¹, \\ Eun Ah Cho', Beom Jun Park', Ki Hyun Kim², Sung Dae Lee ${ }^{3}$ \\ and Jin $\mathrm{Ho} \mathrm{Cho}^{1 *}$
}

\author{
${ }^{1}$ Division of Food and Animal Science, Chungbuk National University, Cheongju 28644, Korea \\ ${ }^{2}$ Animal Welfare Research Team, National Institute of Animal Science, Rural Development \\ Administration, Cheonan 31000, Korea \\ ${ }^{3}$ Animal Nutrition and Physiology Team, National Institute of Animal Science, Rural Development \\ Administration, Cheonan 31000, Korea
}

\section{Abstract}

The objective of this study was to determine the effect of replacing corn with soy hulls on nutrient digestibility of growing pigs. Three experimental diets were tested using a $3 \times 3$ Latin square design using three barrows per group (Landrace $\times$ Yorkshire $\times$ Duroc, average initial body weight of $36.9 \pm 4.0 \mathrm{~kg}$ ) in individual metabolic cages. The dietary treatments were the control (CON) basal diet (corn-soybean meal based diet), whereas in the test diets, soy hulls were included at $5 \%(\mathrm{H} 1), 10 \%(\mathrm{H} 2)$, gradually replacing corn. The daily feed allowance was adjusted to 2.7 times the maintenance requirement for digestible energy (DE) $(2.7 \times 110 \mathrm{kcal}$ of $\left.\mathrm{DE} / \mathrm{kg} \mathrm{BW}^{0.75}\right)$. Intake of crude fiber $(\mathrm{CF})$ was different among treatments $(p<0.05)$. Pigs fed with $\mathrm{H} 2$ diet excreted higher concentrations of dry matter (DM), and CF than pigs fed with $\mathrm{H} 1$ diet and basal diet $(p<0.05)$. Pigs fed with $\mathrm{H} 1$ and $\mathrm{H} 2$ diets excreted higher concentrations of crude protein (CP) than pigs fed with $\mathrm{CON}$ diet $(p<0.05)$. The apparent total tract digestibility (ATTD) of $\mathrm{CF}$ from $\mathrm{H} 1$ and $\mathrm{H} 2$ diets were higher than $\mathrm{CON}$ diet $(p<0.05)$. Pigs fed with $\mathrm{H} 2$ diets were significantly lower $(p<0.05)$ the ATTD of CP than the pigs fed with CON and $\mathrm{H} 1$ diets. The current data suggest that $10 \%$ inclusion soy hulls can slightly decrease CP digestibility. However, soy hulls considerably increased CF digestibility.lt is concluded that $5 \%$ soy hulls may be a usable alternative to corn in growing pig diets.

Keywords: Fibrous feedstuff, Growing pig, Nutrient digestibility, Soy hulls

\section{INTRODUCTION}

Soy hulls is a by-product of producing dehulled or defatted soybean meal and consists of the outer covering of the soybean. Soy hulls contain about $13 \%$ crude protein $(\mathrm{CP}), 35 \%$ crude fiber $(\mathrm{CF})$, abundant mineral $(\mathrm{Ca}, \mathrm{Fe}$, and $\mathrm{P})$, and group $\mathrm{B}$ vitamin content than in other barley feeds [1]. Chee et al. [2] reported that the $\mathrm{CF}$ content of soy hulls (32.5\%) was significantly higher than that of wheat bran (8.7\%). In addition, soy hulls are a great feedstuff because they have a relatively high digestibility due to their low lignin content compared to other grain by-products or plant-based feed ingredients [3]. 
Sung Dae Lee

https://orcid.org/0000-0002-9167-4099

Jin Ho Cho

https://orcid.org/0000-0001-7151-0778

Competing interests

The authors declare no conflict of interest.

Funding sources

This work was supported by the National Research Foundation of Korea (NRF) grant

funded by the Korea government (MSIT) (No. NRF-2019R1F1A1060192).

\section{Acknowledgements}

Not applicable.

Availability of data and material Upon reasonable request, the datasets of this study can be available from the corresponding author.

Authors' contributions

Conceptualization: Oh $\mathrm{HJ}$, Cho $\mathrm{JH}$

Data curation: $\mathrm{Oh} \mathrm{HJ}$

Formal analysis: $\mathrm{Oh} \mathrm{HJ}$.

Investigation: Yun W, Lee JH, An JS, Kim TH, Cho EA, Park BJ, Kim KH, Lee SD.

Writing - original draft: $\mathrm{Oh} \mathrm{HJ}$.

Writing - review \& editing: Cho JH.

Ethics approval and consent to participate The Animal Care and Use Committee of Chungbuk National University approved all the experimental protocols used in the current study.
Fibrous feedstuffs, such as soy hulls are used at appropriate levels for weaning and finishing pigs [4-6]. Fibrous diets have been reported to help improve digestibility by altering the shape of the digestive tract in weaning piglets [7]. Many studies have been conducted in the pig finishing period to analyze the growth performance, nutrient digestibility, and meat quality produced by feeding fiber feed to reduce the cost of feed [8,9]. However, there is an insufficient number of studies on the effects of soy hulls supplementation on nutrient digestibility in growing pigs. In addition, many previous studies on fibrous feed using barley silage, poorly soluble dietary fiber, and straw exist [8-11] and there is a lack of research on soy hulls in pigs. Therefore, we conducted this study to determine the effect of replacing corn with soy hulls on nutrient digestibility of growing pigs.

\section{MATERIALS AND METHODS}

\section{Experiment design and housing}

The protocol for the experiment was approved by the Institutional Animal Care and Use Committee of Chungbuk National University, Cheongju, Korea.

A total of three crossbred (Duroc $\times$ Landrace $\times$ Yorkshire) barrows were allotted to a $3 \times 3$ Latin square design. The pigs (average initial body weight of $36.9 \pm 4.0 \mathrm{~kg}$ ) were individually placed in 1.2 $\mathrm{m} \times 0.7 \mathrm{~m} \times 0.96 \mathrm{~m}$ stainless steel metabolism cages in an environmental controlled room $\left(24 \pm 2^{\circ} \mathrm{C}\right)$.

\section{Diets and feeding}

Table 1 shows the nutrient contents of the soy hulls used in this experiment. The dietary treatments were the control $(\mathrm{CON})$ basal diet (corn-soybean meal based diet), whereas in the test diets, soy hulls were included at 5\% (H1), 10\% (H2), gradually replacing corn (Table 2). The daily feed allowance was adjusted to 2.7 times the maintenance requirement for digestible energy (DE) $(2.7 \times$ $110 \mathrm{kcal}$ of $\mathrm{DE} / \mathrm{kg} \mathrm{BW}^{0.75}$ ) [12]. The allowance was allotted into two equal parts and fed at 08:30 and 17:30 $\mathrm{h}$. The diets were mixed with water in a ratio of 1:1 (Wt/Wt) before feeding. Water was available ad libitum through a drinking nipple. The pigs were individually weighed at the beginning of each period and the amount of feed supplied and any feed residual quantity for each period was recorded. Each experimental period consisted of a 4-day adaptation period followed by a 3-day collection period to collect feces and urine. The fecal and urine were collected by total collection method. Feces were immediately collected when the feces appeared in the metabolism cages, kept in plastic bags and stored in a freezer at $-20^{\circ} \mathrm{C}$ until analyzed.

Table 1. Chemical composition of soy hulls (as-fed basis)

\begin{tabular}{|c|c|}
\hline Item & Content (\%) \\
\hline Moisture & 9.1 \\
\hline Crude protein & 11 \\
\hline Ether extract & 2 \\
\hline Crude fiber & 31 \\
\hline Ash & 4.5 \\
\hline Calcium & 0.4 \\
\hline Phosphate & 0.19 \\
\hline Digestible energy (MJ/kg) & 1.47 \\
\hline Lysine & 0.8 \\
\hline Methionine & 0.17 \\
\hline Threonine & 0.45 \\
\hline Tryptophan & 0.1 \\
\hline
\end{tabular}


Table 2. Formula and chemical composition of the basal and experiment diets (as-fed basis)

\begin{tabular}{|c|c|c|c|}
\hline Item & CON & H1 & $\mathrm{H} 2$ \\
\hline \multicolumn{4}{|l|}{ Ingredients (\%) } \\
\hline Corn & 53.58 & 48.58 & 42.58 \\
\hline Soybean meal & 22.38 & 22.38 & 22.38 \\
\hline Wheat & 14 & 14 & 14 \\
\hline Canola meal & 2 & 2 & 2 \\
\hline Soy hulls & - & 5 & 10 \\
\hline Soybean oil & 2 & 3 & 4 \\
\hline Molasses & 3 & 2 & 2 \\
\hline Limestone & 0.63 & 0.63 & 0.63 \\
\hline Calcium phosphate & 1.47 & 1.47 & 1.47 \\
\hline L-Lysine $\mathrm{HCl}$ & 0.25 & 0.25 & 0.25 \\
\hline DL-Methionine & 0.08 & 0.08 & 0.08 \\
\hline Threonine & 0.03 & 0.03 & 0.03 \\
\hline Choline $\mathrm{Cl}$ & 0.03 & 0.03 & 0.03 \\
\hline Mineral premix ${ }^{1)}$ & 0.1 & 0.1 & 0.1 \\
\hline Vitamin premix ${ }^{2)}$ & 0.2 & 0.2 & 0.2 \\
\hline Salt & 0.25 & 0.25 & 0.25 \\
\hline Total & 100 & 100 & 100 \\
\hline \multicolumn{4}{|l|}{ Calculated value } \\
\hline ME (kcal/g) & 3,341 & 3,328 & 3,304 \\
\hline Crude protein (\%) & 18 & 18 & 18.02 \\
\hline Crude fiber (\%) & 2.13 & 3.82 & 5.48 \\
\hline Lysine (\%) & 1.108 & 1.134 & 1.158 \\
\hline Methionine (\%) & 0.367 & 0.366 & 0.365 \\
\hline
\end{tabular}

${ }^{1)}$ Provided per kg of diet: $12.5 \mathrm{mg}$ manganese, $179 \mathrm{mg}$ zinc, $140 \mathrm{mg}$ copper, $0.5 \mathrm{mg}$ iodine, and $0.4 \mathrm{mg}$ selenium.

${ }^{2)}$ Provided per kg of diet: $20,000 \mathrm{IU}$ of vitamin $\mathrm{A} ; 4,000 \mathrm{IU}$ of vitamin $\mathrm{D}_{3} ; 80 \mathrm{IU}$ of vitamin $\mathrm{E} ; 16 \mathrm{mg}$ of vitamin $\mathrm{K}_{3} ; 4 \mathrm{mg}$ of thiamine; $20 \mathrm{mg}$ of riboflavin; $6 \mathrm{mg}$ of pyridoxine; $0.08 \mathrm{mg}$ of vitamin $\mathrm{B}_{12} ; 120 \mathrm{mg}$ of niacin; $50 \mathrm{mg}$ of calcium pantothenate; $2 \mathrm{mg}$ of folic acid; and $0.08 \mathrm{mg}$ of biotin.

CON, basal diet; $\mathrm{H} 1,5 \%$ replacing corn with soy hulls; $\mathrm{H} 2,10 \%$ replacing corn with soy hulls.

Urine was collected into 18.9L urine collection plastic buckets that were placed under the metabolism cages and collected once a day into $50 \mathrm{~mL}$ of $6 \mathrm{~mol} / \mathrm{L} \mathrm{H}_{2} \mathrm{SO}_{4}$ was added. The collected urine was weighed and stored at $-20^{\circ} \mathrm{C}$. The collection of feces and urine were conducted according to the methods described by Song et al. [13]. Fecal samples were dried at $70^{\circ} \mathrm{C}$ for $72 \mathrm{~h}$ in a forced air oven and ground through a 1-mm screen, and thoroughly mixed before a subsample was collected for chemical analysis. Diets and feces were analyzed for dry matter (DM), CP, CF [14]. The gross energy of diets, feces, and urine were analyzed using an adiabatic oxygen bomb calorimeter (Parr Instruments, Moline, IL). The content of nitrogen in the urine was also analyzed [14].

\section{Statistical analysis}

The data for effects of replacing corn with soy hulls on the apparent total tract digestibility (ATTD) of fiber, dry matter, protein, energy subjected to an Analysis of Variance using PROC GLM of SAS (Statistical Analysis System 9.1, SAS Institute, Cary, NC, USA). 


\section{RESULTS AND DISCUSSION}

In daily balance of nutrient, the intake of crude fiber was different among treatments $(p<0.05$; Table 3). Pigs fed with $\mathrm{H} 2$ diet excreted higher concentrations of DM, and $\mathrm{CF}$ than pigs fed with $\mathrm{H} 1$ diets and basal diet $(p<0.05)$. Pigs fed with $\mathrm{H} 1$ and $\mathrm{H} 2$ diets excreted higher concentrations of $\mathrm{CP}$ than pigs fed with $\mathrm{CON} \operatorname{diet}(p<0.05)$.

The ATTD of crude fiber from $\mathrm{H} 1$ and $\mathrm{H} 2$ diets were higher than CON diets $(p<0.05$; Table 4). Pigs fed with $\mathrm{H} 2$ diet were significantly lower $(p<0.05)$ the ATTD of $\mathrm{CP}$ than the pigs fed with $\mathrm{CON}$ and $\mathrm{H} 1$ diets.

Feeding fibrous diets to pigs has produced a variety of effects. The most prominent effect of dietary fiber supplementation for pigs is changes of the gastrointestinal environment [15]. The addition of fibrous feed to pig diets increases the secretion of swine intestinal fluid [16]. It also reduces the gastric emptying time and increases the digestive viscosity $[17,18]$. Fibrous feed increases the amount of digestion in the stomach, decreases the rate of digestive movement, and increases satiety [19]. Stanogias \& Pearce [20] reported that supplementation of soy hulls and wheat bran to swine diets increased the amount of digested products compared to the basal diet, which resulted in a decrease in the digestive movement speed and a feeling of satiety for better feed efficiency and digestibility. Due to the effects of reduced gastric emptying time, increased digestion viscosity, and

Table 3. Effect of replacing corn with soy hulls on daily balance in nutrient of growing pigs

\begin{tabular}{lccccc}
\hline \multicolumn{1}{c}{ Items } & CON & H1 & H2 & SE & p-value \\
\hline Intake & & & & & \\
Feed intake (g) & 1,700 & 1,708 & 1,725 & 67 & 0.103 \\
Dry matter (g) & 1,664 & 1,692 & 1,694 & 66 & 0.081 \\
Moisture (\%) & 2.1 & 2 & 1.8 & 0.1 & 0.612 \\
Crude fiber (g) & $36.2^{\mathrm{c}}$ & $65.3^{\mathrm{b}}$ & $94.5^{\mathrm{a}}$ & 4.2 & 0.001 \\
Crude protein (g) & 306.0 & 307.4 & 308.7 & 12.6 & 0.096 \\
Energy (kcal) & 7,072 & 6,985 & 7,070 & 276 & 0.317 \\
Excretion & & & & & \\
Fress fecal (g) & 1,453 & 1,495 & 1,508 & 98 & 0.310 \\
Dry matter (g) & $417.5^{\mathrm{b}}$ & $415^{\mathrm{b}}$ & $432.5^{\mathrm{a}}$ & 25.9 & 0.002 \\
Moisture (\%) & 71.3 & 72.7 & 70.9 & 0.6 & 0.073 \\
Crude fiber (g) & $19.81^{\mathrm{b}}$ & $23.4^{\mathrm{b}}$ & $31.9^{\mathrm{a}}$ & 2.1 & 0.015 \\
Crude protein $(\mathrm{g})$ & $74.6^{\mathrm{b}}$ & $82.3^{\mathrm{a}}$ & $83.5^{\mathrm{a}}$ & 3.8 & 0.001 \\
Energy (kcal) & 2,004 & 2,020 & 2,049 & 122 & 0.142 \\
\hline
\end{tabular}

${ }^{a-c}$ Means in the same row with different superscripts differ $(p<0.05)$.

CON, basal diet; $\mathrm{H} 1,5 \%$ replacing corn with soy hulls; $\mathrm{H} 2,10 \%$ replacing corn with soy hulls; $\mathrm{SE}$, standard error.

Table 4. Effect of replacing corn with soy hulls on apparent total tract digestibility (ATTD) of nutrient in growing pigs

\begin{tabular}{lllllc}
\hline \multicolumn{1}{r}{ Items (\%) } & CON & H1 & H2 & SE & $p$-value \\
\hline Dry matter & 74.7 & 76.9 & 74.5 & 2.1 & 0.168 \\
Crude fiber & $43.65^{\mathrm{b}}$ & $63.17^{\mathrm{a}}$ & $64.67^{\mathrm{a}}$ & 2.89 & 0.008 \\
Crude protein & $74.4^{\mathrm{a}}$ & $73.4^{\mathrm{a}}$ & $71.8^{\mathrm{b}}$ & 0.9 & 0.031 \\
Gross energy & 70.3 & 71.6 & 70.1 & 2.6 & 0.206 \\
\hline
\end{tabular}

a,b Means in the same row with different superscripts differ $(p<0.05)$.

$\mathrm{CON}$, basal diet; $\mathrm{H} 1,5 \%$ replacing corn with soy hulls; $\mathrm{H} 2,10 \%$ replacing corn with soy hulls; SE, standard error. 
reduced digestion rate with fibrous feed supplementation, digestion becomes easier and digestibility increases.

In the present study, crude fiber digestibility of growing pigs increased by increasing soy hulls content in diets, but, $\mathrm{CP}$ digestibility decreased. In other studies, the inclusion of graded levels of soy hulls in animal diets decreased DM and GE digestibility by increasing dietary levels of soy hulls [21]. Rainbird [22] and Rainbird \& Low [23] reported that dietary supplementation of CF increases the amount of digestion time in the gastrointestinal tract, resulting in increased DM digestibility of growing pigs. Varel \& Yen [24] reported that the CF digestibility was increased by increasing contents of $\mathrm{CF}$ in swine diets. However, they explained that it also adversely affects digestibility of nutrients. The increase in crude fiber digestibility was accompanied by a corresponding decrease in the digestibility of dry matter, organic matter, crude protein, and nitrogen free extract.

Digestive condition of the stomach and small intestine can be affected by dietary fiber before digestive products reach the large intestine. Lenis et al. [25] reported that dietary fiber in growing pigs diets may decrease in nutrient digestibility due to increased endogenous excretion and/or nutrient absorption. The amount of endogenous nitrogen loss knowledge to distinguish the apparent digestibility of protein and amino acid. Regardless of digestive conditions, true digestibility is an advantage over apparent digestibility in that it is a basic characteristic of feed [26]. Many studies have reported that endogenous protein loss increased by increasing dietary fiber content [27-28, 30]. Mosenthin et al. [29] and Dilger et al. [30] suggested that the protein loss was due to a reduced resorption rate of endogenous nitrogen, not just an increase in nitrogen loss in the small intestine.

\section{CONCLUSION}

Results from the present study indicate that replacing corn with soy hulls in corn-soybean meal based diets can increase crude fiber digestibility of growing pigs. Moreover, there is no difference in CP digestibility between basal diet and 5\% replacing corn with soy hulls in diet. It is concluded that $5 \%$ replacing corn with soy hulls may be a usable alternative to corn in growing pig diets.

\section{REFERENCES}

1. Barbosa FF, Tokach MD, DeRouchey JM, Goodband RD, Nelssen JL, Dritz SS. Variation in chemical composition of soybean hulls. Kans AES Res Rep. 2008;158-65.

2. Chee KM, Chun KS, Huh BD, Choi JH, Chung MK, Lee HS, et al. Comparative feeding values of soybean hulls and wheat bran for growing and finishing swine. Asian-Aust J Anim Sci. 2005;18:861-7.

3. Anderson SJ, Merrill JK, Klopfenstein TJ. Soybean hulls as an energy supplement for the grazing ruminant. J Anim Sci. 1988;66:2959-64.

4. Whitney MH, Shurson GC. Growth performance of nursery pigs fed diets containing increasing levels of corn distiller's dried grains with solubles originating from a modern Midwestern ethanol plant. J Anim Sci. 2004;82:122-8.

5. Weber TE, Ziemer CJ, Kerr BJ. Effects of adding fibrous feedstuffs to the diet of young pigs on growth performance, intestinal cytokines, and circulating acute-phase proteins. J Anim Sci. 2008;86:871-81.

6. Whitney MH, Shurson GC, Johnston LJ, Wulf DM, Shanks BC. Growth performance and carcass characteristics of grower-finisher pigs fed high-quality corn distillers dried grain with solubles originating from a modern Midwestern ethanol plant.J Anim Sci. 2006;84:3356-63.

7. Jin L, Reynolds LP, Redmer DA, Caton JS, Crenshaw JD. Effects of dietary fiber on intestinal 
growth, cell proliferation, and morphology in growing pigs. J Anim Sci. 1994;72:2270-8.

8. Shin SO, Han YK, Cho JH, Kim HJ, Chen YJ, Yoo JS, et al. Effects of rye silage on growth performance, blood characteristics, and carcass quality in finishing pigs. Korean J Food Sci Anim Resour. 2007;27:392-400.

9. Cho JH, Han YG, Min BJ, Chen YJ, Kim HJ, Yoo JS, et al. Effect of feeding rye silage on growth performance, blood and carcass characteristics in finishing pigs. Korean J Food Sci Anim Resour. 2005;25:449-57.

10. Han YK, Han KY, Lee JH. Effects of insoluble dietary fiber supplementation on performance and nutrient digestibility of weanling pigs. J Anim Sci Technol. 2005;47: 565-72.

11. Jha R, Berrocoso JD. Review: dietary fiber utilization and its effects on physiological functions and gut health of swine. Animal. 2015;9:1441-52.

12. National Research Council [NRC]. Nutrient requirements of swine. 11th rev. ed. Washington, DC: The National Academies Press; 2012.

13. Song GL, Li DF, Piao XS, Chi F, Yang WJ. Apparent ileal digestibility of amino acids and the digestible and metabolizable energy content of high-oil corn varieties and its effects on growth performance of pigs. Arch Anim Nutr. 2003;57:297-306.

14. AOAC. Official methods of analysis. 15th Ed. Arlington, VA: Association of Official Analytical Chemists; 1990.

15. Kerr BJ, Shurson GC. Strategies to improve fiber utilization in swine. J Anim Sci Biotechnol. 2013;4:11.

16. Wenk C. The role of dietary fibre in the digestive physiology of the pig. Anim Feed Sci Technol. 2001;90:21-33.

17. Grieshop CM, Reece DE, Fahey GC. Nonstarch polysaccharides and oligosaccharides in swine nutrition. In: Lewis AJ, Southern LL, editors. Swine nutrition. 2nd ed. Boca Raton, FL: CRC Press; 2001.p.107-30.

18. Johansen HN, Knudsen KB, Sandstrom B, Skjoth F. Effects of varying content of soluble dietary fibre from wheat flour and oat milling fractions on gastric emptying in pigs. Br J Nutr. 1996;75:339-51.

19. Miller ER, Ullrey DE, Lewis AJ. Swine nutrition. Stoneham, MA: Butterworth-Heinemann; 2018.

20. Stanogias G, Pearcet GR. The digestion of fibre by pigs: 1 . The effects of amount and type of fibre on apparent digestibility, nitrogen balance and rate of passage. Br J Nutr. 1985;53:513-30.

21. Dilger RN, Sands JS, Ragland D, Adeola O. Digestibility of nitrogen and amino acids in soybean meal with added soyhulls. J Anim Sci. 2004;82:715-24.

22. Rainbird AL. Effect of guar gum on gastric emptying of test meals of varying energy content in growing pigs. Br J Nutr. 1986;55:99-109.

23. Rainbird AL, Low AG. Effect of various types of dietary fibre on gastric emptying in growing pigs. Br J Nutr. 1986;55:111-21.

24. Varel VH, Yen JT. Microbial perspective on fiber utilization by swine. J Anim Sci. 1997;75:2715-22.

25. Lenis NP, Bikker P, van der Meulen J, van Diepen JThM, Bakker JGM, Jongbloed AW. Effect of dietary neutral detergent fiber on ileal digestibility and portal flux of nitrogen and amino acids and on nitrogen utilization in growing pigs. J Anim Sci. 1996;74:2687-99.

26. Mosenthin R. Current concepts of protein digestion and absorption in the pig review. Vet Zootec. 2002;42:30-8.

27. Schulze H, van Leeuwen P, Verstegen MWA, Huisman J, Souffrant WB, Ahrens F. Effect of level of dietary neutral detergent fiber on ileal apparent digestibility and ileal nitrogen losses in 
pigs. J Anim Sci. 1994;72:2362-8.

28. Yin YL, McEvoy JDG, Schulze H, Hennig U, Souffrant WB, McCracken KJ. Apparent digestibility (ileal and overall) of nutrients and endogenous nitrogen losses in growing pigs fed wheat (var. Soissons) or its by-products without or with xylanase supplementation. Livest Prod Sci. 2000;62:119-32.

29. Mosenthin R, Sauer WC, Ahrens F. Dietary pectin's effect on ileal and fecal amino acid digestibility and exocrine pancreatic secretions in growing pigs.J Nutr. 1994;124:1222-9.

30. Degen L, Halas V, Babinszky L. Effect of dietary fibre on protein and fat digestibility and its consequences on diet formulation for growing and fattening pigs: a review. Acta Agric Scand A Anim Sci. 2007;57:1-9. 